\title{
Virtue Education: Josef Pieper’s Vita Contemplativa as Pedagogical Ground
}

\author{
Annette M. Holba \\ Plymouth State University
}

\begin{abstract}
Virtue education in the United States has lost its clout while the corporatization of higher education may be at its peak. The focus of traditional education has shifted from ideas, wisdom, and the love of learning to having a corporate mindset on progress and skills-based knowledge. In many cases, the focus of attention is on remaining viable/sustainable in times of economic decline rather than learning itself, so the resources supporting institutions of higher education are directed into marketing and public relations practices instead of the infrastructure for thinking and learning. This essay draws together three coordinates to make a case for a return to virtue education in the United States. First, the current condition of higher education is shown to have dubiously strayed from a virtue model. Second, the re-emergence of philosophy as a preferred major and its growth in the academy suggest that people realize that something has to change in higher education as they revert back to a broad liberal arts emphasis. Third, a discussion of virtue education from the lens of Josef Pieper's virtue philosophy, grounded in the Vita Contemplativa, offers renewed possibility to reengaged higher education for a sustainable future. Together, I suggest that the tradition of higher education in the United States is no longer viable and return to a virtue education model is an alternative that might make higher education sustainable.
\end{abstract}

Keywords: virtue, education, contemplation, Vita Contemplativa, aesthetic education

By today's standards, virtue education in the United States has lost its clout while the corporatization of higher education may be at its peak. The focus of traditional education has shifted from ideas, wisdom, and the love of learning to having a corporate mindset on progress and skills-based knowledge. In many cases, the focus of attention is on remaining viable/sustainable in times of economic decline rather than learning itself, so the resources supporting institutions of higher education are directed into marketing and public relations practices instead of the infrastructure for thinking and learning. While skills and viability are important in the marketplace, it is detrimental to education to only focus on these things at the exclusion of other learning resources. Moreover, many students are leaving college with more debt today than they accrued in a lifetime generations ago. With the technological revolution ever present upon us, we focus on the newest gadgets and the instant instead of thinking about the aesthetic aspects of education such as happiness, love, and peace. These are concepts that are central to what it means to be human yet they are almost indefinable in a concrete fashion. Strangely enough, while many studies offer evidence of this corporatization of higher education (Donoghue 2008; Washburn 2006), studies are also showing an increase of majors/programs in an area aligned

Annette M. Holba, Ph.D., associate professor, Department of Communication and Media Studies, Plymouth State University, USA; main research fields: Philosophy of Communication, Rhetoric, and Communication Ethics. Email: aholba@plymouth.edu. 
with traditional liberal arts study consistent with what Friedrich Schiller had in mind when he wrote On the Aesthetic Education of Man in 1794 (Horan and Cidade 2011; O’Shaunnessy 2013; Evelyn 2004). In fact, studies show that a broader education that focuses on critical thinking and decision-making is even more important than a technique-based education because a broad education offers the development of transferable skills that can be applied across the marketplace (Horan and Cidade 2011; O’Shaunnessy 2013). So, the time might be right to bring back a model for virtue education grounded in similar concepts that Schiller found to be quite necessary for an aesthetic education as an alternative to programs that are more or less corporatized. Josef Pieper's Vita Contemplativa can reenact and reengage a virtue education model that can counteract consequences of the corporatization of higher education and open an alternative path toward recuperating higher learning in a corporatized future environment.

This essay draws together three coordinates to make a case for a virtue education. First, the current condition of higher education according to recent studies establishes a case that the current condition in higher education has dubiously strayed from a virtue model. Second, the re-emergence of philosophy as a preferred major and its growth in the academy suggest that people realize that something has to change in higher education as they revert back to a broad liberal arts emphasis. Though administrations are not yet on board with this shift as they continue to administer toward either traditional models that ignore the current landscape of change or they jump to the next new thing in education while not thinking critically about what it is that they are doing. Third, a discussion of virtue education from the lens of Josef Pieper's virtue philosophy, grounded in the Vita Contemplativa, offers renewed possibility to reengage higher education for a sustainable future. Together, I suggest that the tradition of higher education is no longer traditional in the sense that there is one model of education that fits all students and all needs and what we see now is splintering of traditions in learning. So, there is no better time to rethink where we are and what we have become in higher education so that we can thoughtfully engage educational literacy that is meaningful, sustainable, and grounded in a much needed frame of virtue.

\section{Loss of Traditional Education and Consequences of the Corporatization Model}

In her recent book proclaiming a coming dark age, Maggie Jackson argues that "the way we live is eroding our capacity for deep, sustained, perceptive attention - the building block of intimacy, wisdom, and cultural progress. Moreover, this disintegration may come at great cost to us and to society. Put most simply, attention defines us and is the bedrock of society" $(2009,13)$. Attention "is taking possession by the mind, in clear and vivid form, of one out of what seems several simultaneously possible objects or trains of thought" (Jackson 2009, 13). William James agures (1890) attention implies a kind of withdrawal from something so that one might deal more effectively with others. Attention then is our focus that leads our thoughts and takes us to wonder. Right now, our attention is changing and has already derailed our thoughts toward an unknown future.

It is inevitable, today we are shaped by distraction-it seduces our attention and takes us on alternative paths in ways that add complexity to an already complex interpretive terrain. Some scholars say we are moving into "a new dark age" (Jackson 2009, 14) which seems so disconnected from our technologically advanced environment-however, it is dangerous if we dispel this warning. While it seems ludicrous to think that we are slipping toward an epistemological cultural decline, the similarities of an impending dark age are not so far away in comparison to the hallmarks of previous/past dark ages.

A dark age is not a one-dimensional time of disintegration; rather, it is "a distinct turning point in history, a 
period of flux that often produces great technological and other gains" while resulting in "declining civilization and a desert-like spell of collective forgetting” (Jackson 2009, 15). The medieval era, ranging from approximately 400-1400 CE, was a turning point such as this and it was also a time of great technological advancements that includes the inventions of eye glasses, glazed windows, fireplaces, windmills, the compass, the mechanical clock, and the rudder (Jackson 2009, 15). Though, by the sixth century, "all of continental libraries had not only disappeared physically but the memory of them was lost to the emerging feudal society" (Jackson 2009, 15). It is clear that these changes do not happen overnight; with advancements in some civilizations come a decline for others (Cahill 1995).

Looking at our current state of experience, we are also seeing a parallel shift: We are in the midst of innovations, flux, and impending decline (Jackson 2009, 15). At best, we are living in a precarious environment (Butler 2004; Standing 2011, 2013). We have recently seen the failure of our global banking system and we are trading our cultural and societal anchors for freedom and technological innovations that are enslaving us without our consent or knowledge. We are plunging into a "culture of mistrust, skimming, and a dehumanizing merging between man and machine" (Jackson 2009, 16). As we unknowingly cultivate this space of and for distraction, we have begun to lose our imaginative capacity for poiesis and our ability to create and preserve wisdom in an aesthetical space of discovery. Thus, some scholars suggest that we are slipping closer and closer to an era of ignorance (Jackson 2009). Technology and inventions are not supposed to be negative or hurtful, and "our tools transport us, our inventions are impressive, but our sense of perspective and shared vision shrivel" (Jackson 2009, 16). Umberto Eco (1986) has called Western society neomedieval comparing us to the first post-Roman millennium in Europe.

Considering the phenomena of attention deficit disorder (ADD) and attention deficit hyperactivity disorder (ADHD), "they signal disturbing slippages in an asset that we cannot afford to lose" our attention (Jackson 2009, 17). The enslavement to technology also marks something related to connecting with other humans. The idea that we can be interconnected through social and digital media to hundreds of others while at the same time developing a sense of having no close confidant, suggest that there are more and more people feeling lonely or alone than 20 years ago (Jackson 2009). When this happens, trust and a sense of dwelling are either lost or at least obscured. Today, when we think about being together, or when we see people together in public, we more often see couples or small group interactions where one eye is on the other and one eye (or hand) is on our gadgets. In the medical field, doctors listen to their patients for "just 18 seconds before interrupting;" in homes where attention deficit disorders are present, two thirds of children in the United States live in a home that "keeps the television on half or more of the time" (Jackson 2009, 22). Healthy and flourishing societies are "built upon learning, contentment, caring, morality, reflection, and spirit" and there is nothing more central to cultivating these conditions than attention and being present with the other (Jackson 2009, 22). Attention is key to sustaining our human capacity to create society and ultimately to exist at all.

Etymologically, attention comes from the Latin words ad and tendere, meaning to "stretch toward" and the connotation implies attention span. Attention can carry us toward our highest good, our goals, and our collective future; but we need a balance. Part of this balance is to grapple with questions related to the human being and the machine. Another part of this balance is concerned with living the "good life" within a technological culture that has not yet learned how to respect knowledge. There are however, some remnants of education past that can help us to balance this deficit and navigate us off the path toward another dark ages - the path of philosophy, unencumbered by its traditional criticism and refocused toward a response that is 
reflective, reflexive, and moving toward a sustaining paraxial endeavor. Embracing the spirit of what Friedrich Schiller refers to aesthetic education; what Søren Kierkegaard refers to as subjective knowing, and what Josef Pieper refers to as the philosophical act of leisure as the basis of culture, we can develop a theory of virtue education that is responsive to our precarious existence as well as move us into a future of a thoughtful, informed, focused, and intellectually endowed future for humanity. What each of these three philosophers has in common is the role of the Vita Contemplativa in their philosophies. The Vita Contemplativa is the central aspect of a virtue modeled educational experience. A philosophy curriculum cultivates the Vita Contemplativa —-here is looking at philosophy as a new preferred major in the United States.

\section{Philosophy: The New Preferred Major}

Corporate America wants philosophy majors because they believe philosophy majors can critically think, employ logic in decision-making, and undergird their work ethic with, well, ethics. All of this require attention and the ability to focus and think. Recent studies indicate that this preference is a result of the problems in our banking system and other economic areas where bad decision making or loose ethics have caused our nation and in some cases, the global economy to take pause and topple over (Fisher and Stripling 2014; Ginsberg 2011). Consequently, studies are now showing an increase in traditional majors, one of which is the fast growing major philosophy (Horan and Cidade 2011; O’Shaunnessy 2013).

Philosophers from Ancient and Renaissance eras, such as Isocrates and Petrarch, suggest that the purpose of a liberal arts curriculum has been to educate the whole person to prepare them for any path in life they might choose. However, today many students are concerned about what they can do with their degree-not so much what their degree (or experience in the curriculum) might do for them. Scholars argue for a return to the humanities in higher education (Kent 2012; Thomas and Beirne 2002; Lamb 2010; Galloway 2012; Decker 2011; Sinek 2009) and this involves a strong emphasis on the philosophy curriculum. The nature of a philosophy curriculum has always been an integral element to education because it permits freedom in cultivating the mind to become a thinker and a learner—someone who is open to new ideas, willing to do hard work to learn and to create.

Employers in almost every field recognize the versatility of an undergraduate education grounded by a major in philosophy (Rozier and Scharff 2013; Dominus 2013; Sinek 2009; Gregoire 2014; Poulsen 2013). Philosophy majors become lawyers, public relations specialists, marketing professionals, policy analysts, doctors, university presidents, teachers, diplomats, and business owners just to name a few. They go into consulting work, banking, financial analysis, and management. Their writing skills prepare them for careers in politics, television, film, theater, advertising, and literature. They become publishers, editors, journalists, researchers, public interest advocates, lobbyists, medical and business ethicists, congressional staffers, political activists, judges, art critics, and just about everything else (including, of course, philosophers). Being able to think hard is a transferable skill and a skill that employers in all fields are looking for. Thinking hard enables one to successfully navigate general problem-solving and the ability to assess complex data. Thinking hard enables development of competent communication skills, the ability to persuade ethically and the necessary skill of competent writing in various mediated formats. Thinking hard enables students to think cross-disciplinarily and develop sound methods of research and analysis.

We can also provide measurable outcomes as philosophy majors have extremely high acceptance rates to master's and doctoral programs in the Humanities and Social Sciences to Law Schools, to Masters in Business 
Administration Programs, and even to Medical Schools because of their higher test scores. ${ }^{1}$ The professional literature in these areas recommends that future humanities and social science professors as well as future researchers, lawyers, business practitioners, and doctors pursue the kind of broad liberal arts education that is standard in studying philosophy.

What we need now is to recuperate a philosophically grounded virtue model of education that can offset the professional skills/vocational focused educational structure that has become more common within institutions of higher education. Illuminating the philosophical coordinates of a virtue-based education provides a starting place from which this transformation can emerge.

\section{Bringing Back Virtue Education: A Philosophical Foundation}

Associate Dean of Barrett: The Honors College at Arizona State University, West, Ramsey Eric Ramsey (2011), argues that virtue based education might be considered by some as "useless" and while he disagrees with that sentiment; he argues that "useless" is not equivalent to "worthless." As a philosopher first, an educator second, and an administrator in the system of higher education, Dean Ramsey is clear that we should not discard philosophy and virtue education so quickly. It is through the dialogic exchange in the doing of philosophy that we create critical thinkers who have the ability to engage innovative and imaginative problem solving critically, logically, and embedded within a human environment that is responsive and attentive to the other. This takes deep thinking, hard thinking, and a rationality that is not limited to a skills-based knowledge acquisition.

Friedrich Schiller outlines a virtue education in his book On the Aesthetic Education of Man (1954/2009). Originally published in 1795, Schiller cultivates the backdrop for a virtue model of education by starting with the thesis, "art should be the basis of education" (Schiller 1954/2009, 17). Schiller positions art and aesthetic sensibilities as being the core to learning and literacy. The reason why he opens with this is simple enough that art is related to beauty, which has a direct impact on happiness and "moral nobility of human nature" (23). This then leads the human being to freedom, though he defines freedom differently from our modern conceptualizations. For Schiller (1954/2009), freedom involves the capacity to reason-the remodeling of an idea that removes human beings from their "sensuous slumber" recognizing him or herself as a human being, and looks to find him or herself (28). In this state of nature, the necessity of rationality is translated into a moral state, imbuing ethics into the human condition through a cultivated learning.

When human beings have the kind of education and leaning that is grounded upon this kind of freedom, moral sensibilities are cultivated as natural consequences and the task of existence is then to harmonize with the others also in existence (Schiller 1954/2009). When Schiller writes these letters on aesthetic education, he is also calling forth a response to his contemporaries because he foregrounds that the training of the aesthetic sensibilities is more pressing because it means there would come with an improved understanding of life for better living. Schiller's historical moment is not much different from our current historical moment; humanity has again found itself at a crossroad—from this we might learn about our future.

Aesthetic education is an awakening. This kind of awakening is also something that Joseph Pieper discusses in his theory of leisure, a theory that attunes one to the world of ideas, possibilities, and openness to what is not-yet-present. Pieper's perspective includes an understanding of the nature of leisure and how leisure constitutes a good life, a virtuous life, the foundation of culture, and necessary nourishment for the human soul/interiority through learning. 
Josef Pieper was born in 1904 in Germany and is a philosopher first and a medieval theologian second. He attended the Gymnasium Paulinum as a young man, which is where we begin his studies of St. Thomas Aquinas. Known by many scholars as a philosopher steeped in the Thomist tradition, Aquinas had a profound influence on Pieper's philosophy. While Pieper's work is extensive, this essay is most concerned with his virtue philosophy as it is linked to the Vita Contemplativa.

Pieper (1952/1998) has written a lot on the contemplative life. In his theory of leisure, he suggests that leisure is a catalyst for catharsis of the human spirit. Pieper discusses this releasement from the oppression of the self in that through the contemplative spirit, one can be released from one's desires, thus, creating a path toward God. Many philosophers accept this sacred positioning of contemplation as a path that can lead one to God. However, my reading of Pieper is not a religious reading. Instead, a secular approach to Pieper's thought carries with the idea of the contemplative spirit and life is one that permits one to be present here and now, tending and attuning to the face of the other as one engages the other. Where Pieper would say that leisure cultivates one's soul, I argue that leisure grounded in a contemplative spirit cultivates one's interiority. This interior dwelling place is the space where intellectual attunement occurs, a reminder to engage akroatic thinking and move toward ethics of attunement (Lipari 2014). This is how, in a secular understanding, we can be released from the oppression of the self. Pieper reminds the modern world of the philosophical foundation of the act of leisure as a philosophical act itself because it involves learning and hard thinking through a contemplative doing.

Pieper describes the action of leisure as the beginning with a contemplative spirit and removed from everyday business and goal-seeking actions. Understanding leisure in this sense, we see it as actually being hard work; not laziness or idleness. In fact, our actions in leisure Pieper argue that the doing of leisure is a philosophical act that, and if practiced or habituated daily, enables one to philosophize. So, doing leisure habituates one's ability to reason, to philosophize, or to wonder. Wonder is the key to contemplation; it is a way of playing with ideas that enables one to see beyond the obvious or beyond the emotional; it takes a focus of open attention to be able to wonder. Leisure cultivates one's ability to wonder and philosophize. When we do this, we learn to see the world differently and we then develop a different kind of ontological orientation to the world. Pieper's commitment to virtue is a primary force in his philosophy. Education that practices and reinforces contemplative virtue is key to developing a virtue education approach in higher education. There are particular virtues that can undergird experiences in higher education. Applying a virtue approach in the classroom involves promoting dialogue, discussion, and a pedagogy that is open to change and growth.

Starting with Josef Pieper's (2007/1954) discussion of The Four Cardinal Virtues, he identifies the four cardinal virtues as prudence, justice, fortitude, and temperance. Prudence, as the first virtue listed by Pieper, is the mother of all of the other cardinal virtues, the genitrix virtutum. Unlike our contemporary understanding of prudence as a timorous small-minded, self-preservational trait, Pieper asserts that prudence is the realization that the good presupposes knowledge of reality, which means that our actions are appropriate to the particular situation in which we find ourselves. Therefore, our actions involve doing which is right and good for the context. This assumes that one's perception of a given situation is accurate. To know this sense of real, one must be able to see the real and we do this through philosophizing. We also then can assess what we ought to do and how we should apply our actions in a responsive way in particular given situations. Prudence is part of the classical definition of goodness for Pieper, which is a noble seeking toward the classical notion of what is good. This understanding of prudence is elevated to a higher plane than how we use the word today. In higher 
education, prudence is grounded in the relationship between theory and practice or praxis, as well as phronesis.

Pieper's second cardinal virtue is justice, which implies that justice is a habit (habitus), whereby one renders to each one or other what is due without deviation; it is a perpetual pursuit. Pieper's understanding of justice is consistent with Plato's account that states it is the idea that each person is to receive what is due based upon her/his own actions. Pieper suggests that what is "due" may or may not be an inalienable possession but he does say that justice cannot be fully developed outside of a broader, larger moral doctrine. This means that justice cannot be considered outside of or separate from other aspects of morality. Justice only becomes intelligible when it is within the story of a human being, situated within a moral context and within lived action because justice is related to one's relation with the other. Pieper suggests that justice pertains to the idea of righteousness in the sense that it is not limited to the doing of a right thing but also, and more importantly, "to be just as well” $(2007 / 1954,63)$. Pieper is teaching that being a particular way must be consistent with one's actions. Just doing something that looks good is not good enough. Borrowing from Thomas Aquinas on Being and Existence, the virtuous person must, at her or his essence, just, as well as in her or his existence, do things that are just. A virtue education would embody this sense of justice as a practice or habitus of learning.

Fortitude is the third cardinal virtue, which presupposes vulnerability toward death in that it stands in the presence of death, implying a readiness to die or to fall in battle. In this stance of readiness, one must take risks; the highest level of fortitude is martyrdom. Fear is part of the endurance and attack of fortitude and it means to stand up for the good that one knows is right. Fortitude enables one to move, in fear, toward the good that one seeks. Suffering is also part of fortitude because it means that one does not give up with things which get tough. In fortitude, one stays the course and remains through the suffering in times of difficulty. So, in fortitude, one continues to press forward toward the good and it would be unethical to give up the battle; one must be willing to lose in order to gain. Virtue education would adapt various pedagogies that inspire fortitude. This requires commitment and fortitude itself on educators as well as students. Additionally, having fortitude teaches educators to hone their craft and not give into outdated or past practices/traditions that are no longer relevant for our historical moment.

The last cardinal virtue is temperance. Temperance aims at the person herself or himself instead of the action of giving up for others or doing something for others. Temperance suggests that a person should look inward at herself or himself and it points toward a realization of an order in oneself. Today, temperance is thought of as a moderation of vices but this severely limits our understanding of Pieper's argument. The telos of temperance requires a person to search her/his inner self and put one's self in order and only then can an inner serenity occur. A virtue education might incorporate contemplative pedagogy that is designed to enable students to explore their own interiority and learn about themselves as human beings and their ability to think hard and wonder. Temperance enables cultivation of one's inner space because that is its only focus; the playground of temperance is one's interiority.

These short explanations of Pieper's explication of the four virtues represent a broad range of ideas that move us toward a theory of virtue education. Adding to this, Pieper's perspective on philosophy also informs a virtue education. In Defense of Philosophy (1992/1966), Pieper considers the question whether or not a philosophical question can be answered at all and whether the value of philosophy has utility in itself. He suggests that philosophy is no ordinary activity and that is essentially and inescapably connected to praxis. So, we cannot avoid philosophy especially in higher education because that is where we come to understand the why's and how's behind the doing or behind our actions. Education would be insufficient and incomplete 
without it.

Pieper's perspective on virtues, leisure, and philosophy might lay a foundation in higher education for us that reminds us of nobility, the noble path of finding one's fullest potential. This is what education must be focused upon, not the corporatization of an age old tradition. We do not have to sell out education through a corporatization model. We need prudence in decision-making from the administration in higher education to the daily pedagogical decisions we make everyday in the classroom. We need to embody justice with our actions and assignments and grading practices—-we need to offer learning experiencing for student so that they can experience justice in a multitude of ways both in and out of the classroom. Students need to develop a sense of fortitude-our learning outcomes should be important and relevant to students while cultivating as sense of attunement and ethics toward the other that students choose to embrace. As educators, we also ought to model temperance and offer experiential learning moments for students to come to a subjective epistemological ground, the kind that Kierkegaard discusses as introspection and knowledge providing internal justification.

\section{Conclusion}

The landscape of higher education has great potential but has taken the wrong path. Returning to a virtue model for higher education can counteract the dilemma in which we now find ourselves. But all is not lost. Let's take our till to the land and turn over the educational terrain that is marred by the errors of corporatization and the precarious environments in higher education. By integrating Josef Pieper's virtue philosophy in the theory and practice of higher education today, we can begin to reshape the educational terrain in the United States and put the virtue back into higher learning, thinking, doing, and being.

\section{Notes}

1. Sources: Chronicle of Higher Education, Almanac of Higher Education, 1996. Educational Testing Service, "Guide to the Graduate Record Examination Program, 1996-1997.” American Bar Association, "Preparation for a Legal Education.” Association of American Law Schools, "Policy on Pre-legal Education.” Law School Admissions Council, "1996 Data Services Group Report.” American Bar Association, “LSAT Data File, 1996-1997.” Graduate Management Admission Council, "Profile of Graduate Management Admissions Test Candidates, 1997-1998 to 2001-2002.” American Association of Medical Colleges, “Characteristics of the 1999 MCAT Examinees, 1999” and “Applicants Matriculant File, 11/22/2000.”

\section{Works Cited}

Butler, Judith. The Precarious Life. NY: Verso, 2004.

Cahill, Thomas. How the Irish Saved Civilization: The Untold Story of Ireland's Heroic Role From the Fall of Rome to the Rise of Medieval Europe. New York: Nan A. Talese, Doubleday, 1995.

Dominus, Susan. "How to Get a Job With a Philosophy Degree.” < http://www.nytimes.com/2013/09/15/magazine/how-to-get-ajob-with-a-philosophy-degree.html?_r=0>.

Donoghue, Frank. The Last Professors: The Corporate University and the Fate of the Humanities. NY: Fordham University Press, 2006.

Eco, Umberto. Travels in Hyper Reality: Essays. San Diego: Harcourt Brace Jovanovich, 1986.

Evelyn, Jamilah. “Can Philosophy Exist?” Chronicle of Higher Education, 2004. <http://chronicle.com/article/Can-PhilosophyExist-/22478/>.

Fischer, Karin, and Jack Stripling. “An Era of Neglect.” The Chronicle of Higher Education 60.25 (2014): 23.

Galloway, Sarah. "Reconsidering Emancipatory Education: Staging a Conversation Between Paulo Freire and Jacques Ranciére.” Educational Theory 62.2 (2007): 163-84. 
Ginsberg, Benjamin. Fall of the Faculty. NY: OU Press, 2011.

Gregoire, Carolyn. “The Unexpected Way Philosophy Majors Are Changing Business.” Huffington Post. <http://www.huffingtonpost.com/2014/03/05/why-philosophy-majors-rule_n_4891404.html>.

Horan Dan P., and Melissa A. Cidade. "Major Changes Toward Philosophy and Theology: Interpreting a Recent Trend for Millennials in Catholic Higher Education.” Journal of Catholic Higher Education 30.1 (2011): 133-50.

Jackson, Maggie. Distracted: The Erosion of Attention and the Coming Dark Age. NY: Prometheus Books, 2009.

James, William. The Principles of Psychology. Ed., Frederick Burkhardt. Cambridge: Harvard University Press, 1890/1981.

Kent, Eliza F.. "What Are You Going to Do With a Degree in That: Arguing for the Humanities in an Era of Efficiency. Arts and Humanities in Higher Education 11.3 (2012): 273-84.

Lamb, Sharon. "Toward a Sexual Ethics Curriculum: Bringing Philosophy and Society to Bear on Individual Development.” Harvard Educational Review 80.1 (2010): 81-105.

Lipari, Lisbeth. Listening, Thinking, Being: Toward an Ethics of Attunement. NY: SUNY, 2014.

O’Shaunnessy, Lynn. “What Employers Want in College Grads.” CBS News: Money Watch. <http://www.cbsnews.com/news/what -employers-want-in-college-grads/>.

Pieper, Josef. Faith, Hope, Love. San Francisco: Ignatius Press, 1997.

Pieper, Josef. The Four Cardinal Virtues. Notre Dame: University of Notre Dame Press, 1954/2007.

Pieper, Josef. In Defense of Philosophy. San Francisco: Ignatius Press, 1966/1992.

Pieper, Josef. Leisure: The Basis of Culture. South Bend: St. Augustine Press, 1952/1998.

Piety, M. G.. Ways of Knowing: Kierkegaard's Pluralist Epistemology. Waco: Baylor University Press, 2010.

Poulsen, Anders B.. "Why Future Business Leaders Need Philosophy." Rethinking Management Education, 2013. <http://graspmag.org/education/rethink-mgmt-edu/why-future-business-leaders-need-philosophy/>.

Ramsey, Ramsey Eric. "On the Dire Necessity of the Useless: Philosophical and Rhetorical Thoughts on Hermeneutics and Education in the Humanities.” Paul Fairfield, ed.. Education, Dialogue, and Hermeneutics. NY: Continuum, 2011. 91-105.

Rozier, Michael and Darcell, Scharff. "The Value of Liberal Arts and Practices in an Undergraduate Public Health Curriculum.” Public Health Reports 28.5 (2013): 416-21.

Schiller, Friedrich. On the Aesthetic Education of Man. NY: Dover, 1954/2009.

Sinek, Simon. Start With Why: How Great Leaders Inspire Everyone to Take Action. NY: Portfolio, 2009.

Standing, Guy. "Preface: The Dangerous Class.” Chris Dunkley, ed.. The Precariat. London: Oberon Books, 2013. 21-24.

Standing, Guy. The Precariat: The New Dangerous Class. NY: Bloomsbury Press, 2011.

Thomas, Sydney C. and Piers, Beirne. "Humane Education and Humanistic Philosophy: Toward a New Curriculum. Journal of Humanistic Counseling, Education, and Development 41 (2002): 190-9.

Washburn, Jennifer. University, Inc.: The Corporate Corruption of Higher Education. NY: Basic Books, 2006.

White, John. “Reassessing 1960s Philosophy of the Curriculum.” London Review of Education 3.2 (2005): 131-44. 